\title{
Fluid evolution and hydrothermal processes of the Spanish Central System
}

\author{
E. Vindel, J.A. López, T. Martín-Crespo*, E. García \\ Department of Crystallography and Mineralogy, Complutense University, Madrid, Spain
}

\begin{abstract}
Fluids related to veins and hydrothermal alterations from the Spanish Central System have been studied. Fluid chemistry has been established using microthermometry and Raman spectroscopy. Special attention has been paid to the evolution of $P-T$ conditions from early $\mathrm{H}_{2} \mathrm{O}-\mathrm{NaCl}-\mathrm{CO}_{2}-\mathrm{CH}_{4}$ to later $\mathrm{H}_{2} \mathrm{O}-\mathrm{NaCl}-\mathrm{CaCl}_{2}$ fluids. The different types of fluid systems investigated can be distinguished by their fluid pressure, temperature and salinity features. Under initial conditions the fluid pressure may be high, at lithostatic values, and show a nearly isobaric evolution. The later aqueous fluids drop to hydrostatic pressure with a transition to low pressures, in part due to uplift and erosion.
\end{abstract}

Keywords: fluid inclusion; hydrothermal fluid; $P-T$ evolution; Spanish Central System

\section{Introduction}

The Spanish Central System is a northeast trending mountain chain located in the inner zone of the Hercynian Belt in Spain. It is characterised by the presence of high to medium grade autochthonous metamorphic formations, mostly pre-Hercynian orthogneisses and some pre-Ordovician metasediments, and late Hercynian peraluminous granites (Villaseca et al., 1998). These granitoids form the Guadarrama Range and were emplaced between 345 and $285 \mathrm{Ma}$ (Ibarrola et al., 1987). Several episodes of hydrothermal activity related to periods of fracturing and/or reactivation of previous structures took place from 300 to at least $100 \mathrm{Ma}$ (Caballero et al., 1992). Chronologically, the hydrothermal alterations are as follows: (1) 300$290 \mathrm{Ma} \mathrm{W}(\mathrm{Sn})$ - polymetallic sulphide lodes and

\footnotetext{
* Corresponding author. Fax: + 34-91-3944872.

E-mail address: tmartin@eucmax.sim.ucm.es

(T. Martín-Crespo).
}

greisens; (2) $260 \mathrm{Ma}$ skarn deposits; (3) 260$220 \mathrm{Ma}$ episyenites; (4) As(Ag) veins; (5) 151$156 \mathrm{Ma} F(\mathrm{Ba})$ lodes; and (6) $100 \mathrm{Ma}$ barren quartz lodes. The objective of this paper is to document the evolution in the fluid chemistry and the $P-T$ conditions during the hydrothermal activity in the Spanish Central System.

\section{Analytical methods}

Microthermometric characterisation of the fluids was performed using a Linkam THMSG 600 stage. The stage was calibrated with the melting-point of solid standards at $T>25^{\circ} \mathrm{C}$ and natural and synthetic inclusions at $T<0^{\circ} \mathrm{C}$. The rate of heating was monitored in order to obtain an accuracy of $\pm 0.2^{\circ} \mathrm{C}$ during freezing, and $\pm 1^{\circ} \mathrm{C}$ when heating over the $25-400^{\circ} \mathrm{C}$ range and $\pm 4^{\circ} \mathrm{C}$ over the $400-60^{\circ} \mathrm{C}$ range.

Salinity is expressed as equivalent $w t \%$ of $\mathrm{NaCl}$ and was calculated from measurements of the ice melting temperature ( $T_{\mathrm{m}}$ ice) using the equations of 
Bodnar (1993). The composition of $\mathrm{H}_{2} \mathrm{O}-\mathrm{NaCl}-$ $\mathrm{CaCl}_{2}$ fluids was established using the Microsoft Excel Add-in Naden (1996). Salinity of hypersaline inclusions was calculated from the halite dissolution temperature. $\boldsymbol{P}-\boldsymbol{T}$ properties for the $\mathrm{H}_{2} \mathbf{-}-\mathrm{NaCl}$ system were obtained using data from Zhang and Frantz (1987). In gas-rich fluid inclusions, $\mathrm{CO}_{2}$ was identified by melting of a solid below $-56.6^{\circ} \mathrm{C}$. Molar fractions of $\mathrm{CO}_{2}, \mathrm{CH}_{4}, \mathrm{H}_{2} \mathrm{~S}$ and $\mathrm{N}_{2}$ were determined in individual inclusions by micro-Raman analysis performed (at CREGU, Nancy) on a DILOR X-Y multichannel modular Raman spectrometer.

Bulk composition and molar volume were computed from the $\boldsymbol{P}-V-\boldsymbol{T}-X$ properties of individual inclusions in the $\mathrm{C}-\mathrm{-}-\mathrm{H}-(\mathrm{N}-\mathrm{S})$ system (Dubessy et al., 1992; Thiery et al. 1994). The $\boldsymbol{P}-\boldsymbol{T}$ properties of aqueous-carbonic inclusions were modelled for the system $\mathrm{H}_{2}-\mathrm{NaCl}-\mathrm{CO}_{2}-\mathrm{CH}_{4}$ using the $V-X$ data and the equation of state of Jacobs and Kerrick (1981).

\section{Fluid characterisation}

Based on thermometric studies and Raman analysis, three main types of fluids have been distinguished:

1. Hypersaline aqueous fluid $\left(\mathrm{H}_{2}-\mathrm{NaCl}\right)$. The fluid is represented by three phase inclusions, including one or more solid phases (halite and/or silvite) and unknown trapped minerals with global homogenisation on liquid. Total homogenisation temperature $\left(T_{\mathrm{h}}\right)$ ranges from 200 to $400^{\circ} \mathrm{C}$ and salinity from 29 to $53 \mathrm{wt} \% \mathrm{NaCl}$ eq. This type has only been recognised as primary inclusions in quartz from greisen close to the $\mathrm{W}(\mathrm{Sn})$ veins and never in the veins or in other mineralisation types; therefore an early magmatic origin can be inferred.

2. Metamorphic aqueous-carbonic fluid. The fluid is represented by two types of fluids:

2.1. $\mathrm{H}_{2}-\mathrm{NaCl}-\mathrm{CO}_{2}-\mathrm{CH}_{4}$ fluids $\left(\mathrm{H}_{2} \bullet 52 / 95.5\right.$, $\mathrm{CO}_{2} \quad 1.3 / 36, \mathrm{CH}_{4} \quad \mathbf{0 . 1 / 2 . 5}$ and $\mathrm{N}_{2}$ nd-3.5 $\mathrm{mol} \%$ ) show $T_{\mathrm{h}}$ in vapour or liquid between 350 and $420^{\circ} \mathrm{C}$.

2.2. $\mathrm{H}_{2}-\mathrm{NaCl}-\mathrm{CH}_{4}$ fluid $\left(\mathrm{H}_{2} \bullet 87 / 94\right.$ and $\mathrm{CH}_{4}$ 4.9/12.6 mol\%). The $T_{\mathrm{h}}$ ranges between 210 and $370^{\circ} \mathrm{C}$ in liquid.

3. These fluids are recognised only in the oldest hydrothermal event, quartz associated to $\mathrm{W}(\mathrm{Sn})$ polymetallic sulphides, and in $\mathrm{As}(\mathrm{Ag})$ veins. The first fluid (1) is related to woltramite and arsenopyrite deposition and the $\mathrm{CH}_{4}$-rich fluid (ii) to $\mathrm{Cu}-$ $\mathrm{Zn}-\mathrm{Pb}$ sulphide deposition. The evolution of aqueous-carbonic fluids reveals a progressive enrichment in water and $\mathrm{CH}_{4}$ content. These C$\mathrm{H}-\mathbf{- N}$ fluids can be explained as resulting from water interaction within the metamorphic host rocks (metamorphic fluids). The $\mathrm{CO}_{2} / \mathrm{CH}_{4}$ ratio points to reactions between $\mathrm{H}_{2}$ and graphite at temperatures approximately around $400^{\circ} \mathrm{C}$ (Vindel et al. 1995). Preliminary data of $\delta \mathrm{D}$ and $\delta^{18}$ exclude a magmatic origin and suggest processes involving the surrounding metamorphic rocks (Tornos et al., 1996).

4. Aqueous fluid. Aqueous fluid inclusions are ubiquitous. They occur either as primary fluid inclusions in quartz from epysienites, fluorite-barite and barren quartz veins or as fluid inclusion planes in quartz from wolframite and $\mathrm{As}(\mathrm{Ag})$ lodes. Three types of fluids have been identified, all aqueous; C-N-S species were not detected either by microthermometry or Raman spectroscopy. Stable isotope data indicate a meteoric origin for the aqueous fluids (Tomos et al., 1996).

4.3. $\mathrm{H}_{2}-\mathrm{NaCl}$ fluid-Primary fluid inclusions from barren quartz show salinity lower than $1 \mathrm{wt} \% \mathrm{NaCl}$ eq. and $T_{\mathrm{h}}$ between 140 and $300^{\circ} \mathrm{C}$. Aqueous fluid inclusions in fluoritebarite veins are more saline (fluorite: $10.5 \mathrm{wt} \% \mathrm{NaCl}$ eq; barite: $3.4-14 \mathrm{wt} \%$ $\mathrm{NaCl}$ eq.) and $T_{\mathrm{h}}$ lies between 120 and $270^{\circ} \mathrm{C}$ (Tornos et al., 1991). Secondary fluid inclusions belonging to this type are recognised in quartz-wolframite, sulphides and As( $(\mathrm{Ag})$ lodes. Bulk salinity ranges between 2.6 and $8.9 \mathrm{wt} \% \mathrm{NaCl}$ eq. and homogenisation temperatures between 90 and $380^{\circ} \mathrm{C}$

4.4. $\mathrm{H}_{2}-\mathrm{NaCl}-\mathrm{CaCl}_{2}$ fluid-Lacking in Wpolymetallic sulphide veins and $\mathrm{As}(\mathrm{Ag})$ lodes, they are characteristic of barren quartz veins. Eutectic temperatures range from -65 to $-55^{\circ} \mathrm{C}$ and the brown ice is diagnostic of the presence of $\mathrm{CaCl}_{2}$, but the temperatures are lower than the theoretic eutectic temperatures corresponding to the $\mathrm{H}_{2}-\mathrm{NaCl}-$ $\mathrm{CaCl}_{2}$ system $\left(-52^{\circ} \mathrm{C}\right)$. The lower values could result from the presence of additional components, such as $\mathrm{LiCl}$, which depress 


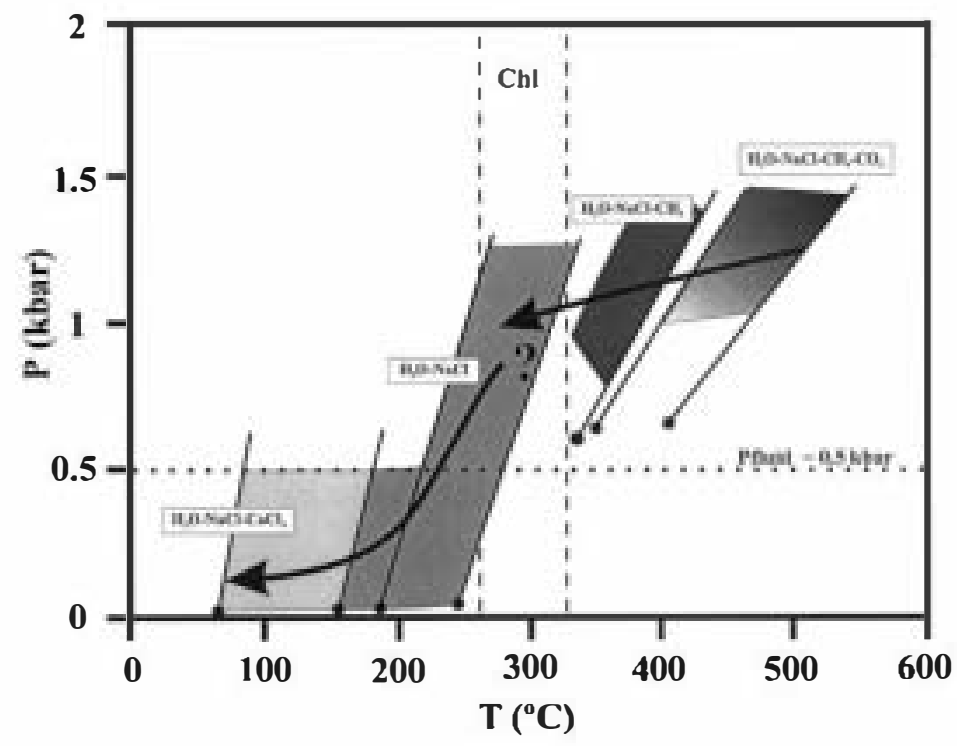

Fig. 1. P-T diagram illustrating the evolution of fluids related to hydrothennal processes in the Spanish Central System.

$\mathrm{H}_{2} \mathrm{O}-\mathrm{NaCl}-\mathrm{CaCl}_{2}$ eutectic (Davis et al., 1990). Preliminary analyses using Laser Ablation Optical Emission Spectrometry demonstrated the presence of Li. The composition of these fluids using $T_{\mathrm{m}}$ ice and $T_{\mathrm{m}}$ hydrohalite according to Naden (1996) ranges between 16 and $24 \mathrm{wt} \% \mathrm{NaCl}$ and $1-12 \mathrm{wt} \% \mathrm{CaCl}_{2}$, with low homogenisation temperatures, $70-160^{\circ} \mathrm{C}$. Finally, a high salinity Ca-rich fluid represents the latest event in the hydrothermal evolution of the Spanish Central System. The fluid inclusions contain three phases at room temperature including daughter crystal (halite). They are secondary and postdate the other types. An approximation of the bulk salinity has been calculated between 30 and $38.1 \mathrm{wt} \% \mathrm{NaCl}$ eq. and the estimated composition (Naden, 1996) ranges between 7 and $15 \mathrm{wt} \% \mathrm{NaCl}$ and 21 and $27 \mathrm{wt} \% \mathrm{CaCl}_{2}$. Homogenisation temperatures range between 60 and $170^{\circ} \mathrm{C}$ and dissolution temperatures of halite between 120 and $220^{\circ} \mathrm{C}$.

5. The general evolution of aqueous fluids is to increasing salinity with decreasing temperature. The $\mathrm{CaCl}_{2}$ brines as primary inclusions are restricted to vug quartz crystals in the centre part of barren quartz veins, which represent the most recent hydrothermal event in the studied area.

\section{4. $P-T$ estimation}

The $\boldsymbol{P}-\boldsymbol{T}$ reconstruction of conditions prevailing for the several episodes of hydrothermal activity of the Spanish Central System is given in Fig. 1.

The $P-T$ path is characterised by a nearly isobaric evolution in the early stage. The aqueous-carbonic fluids circulated at pressures ranging from 0.75 to $1.25 \mathrm{kbar}$ and 330 to $500^{\circ} \mathrm{C}$. The higher $P-T$ $\left(1.25 \mathrm{kbar}\right.$ and $500^{\circ} \mathrm{C}$ ) correspond to $\mathrm{H}_{2} \mathrm{O}-\mathrm{NaCl}-$ $\mathrm{CO}_{2}-\mathrm{CH}_{4}$ fluids related to wolframite deposition. The spatial relationship between more diluted fluids $\left(\mathrm{CH}_{4}\right.$ bearing) and the main sulphide and chlorite deposition indicates, using the Cathelineau geothermometer (Cathelineau, 1988), a crystallisation

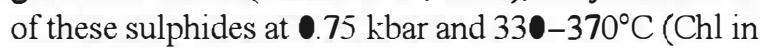
Fig. 1). This early fluid pressure may be at lithostatic values.

Results from aqueous fluids emphasise the difficulties of interpreting samples in which a long history of fluid flow events have become superimposed. The $P_{-}$ $T$ evolution of aqueous fluids is mainly recorded from 70 to $330^{\circ} \mathrm{C}$ and 0.15 to $1 \mathrm{kbar}$. As evidence of boiling 
has not been recognised and a mineral geothermometer is not available, fluid pressure is assumed to be $\left(\boldsymbol{P}_{\mathrm{h}}\right.$. The vuggy textures and brittle nature of the host rock are taken to indicate a hydrostatic pressure regime for these fluids. Emplacement pressure for host granites is nearly $2 \mathrm{kbar}$ corresponding to a depth between 5 and $8 \mathrm{~km}$ at lithostatic pressure (Villaseca et al., 1998). If the pressure regime in the quartz veins is entirely hydrostatic, a depth of $5 \mathrm{~km}$

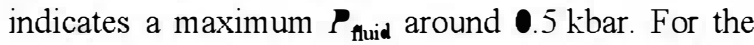
pressure range $\mathrm{CaCl}_{2}$-rich fluids were trapped at 70 $140^{\circ} \mathrm{C}$

The relationship between aqueous-carbonic and aqueous fluids remains unclear. They display two distinct evolutions at decreasing temperature with no clear evidence of mixing between the two. $\mathrm{W}(\mathrm{Sn})$ and As( $\mathrm{Ag})$ hydrothermal mineralisation are related to the high temperature and isobaric evolution. F (Ba) and barren quartz veins are characterised by the low $\boldsymbol{P}-\boldsymbol{T}$ evolution.

\section{Conclusions}

Successive changes in fluids have been documented in relation to the long hydrothermal activity of the Spanish Central System. The early mineralisation stage (W(Sn)-sulphides, As-Ag) is characterised by aqueous-carbonic fluids. Hypersaline fluids are scarce and restricted to the greisen. Aqueous fluids of meteoric origin are recognised in all mineralisation types as primary or secondary fluid inclusions. Aqueous Ca-rich fluids characterise the latest stage as primary fluid inclusions in quartz crystal from barren quartz veins. At the early stage, the fluid evolution shows a drop in temperature $\left(500-330^{\circ} \mathrm{C}\right)$ at lithostatic conditions $(1.25-0.75 \mathrm{kbar})$. The recent stage $\left(330-70^{\circ} \mathrm{C}\right)$ displays low pressures $(1-$ 0.15 kbar) at hydrostatic conditions. There is no evidence of boiling in the area and the features of the fluids suggest two independent fluid evolutions not related in time.

\section{References}

Bodnar, R.J., 1993. Revised equation and table for determining the freezing point depression of $\mathrm{H}_{2} \mathrm{O}-\mathrm{NaCl}$ solutions. Geochim Cosmochim. Acta 57, 683-684.

Caballero, J.M., Casquet, C., Galindo, C., Gonzalez-Casado, J.M., Snelling, N., Tornos, F., 1992. Dating of hydrothermal events in the Sierra de Guadarrama, Iberian Hercynian Belt, Spain. Geogaceta 11, 18-22.

Cathelineau, M., 1988. Cations site occupancy in chlorites and illites as a function of temperature. Clay Miner. 23, 471-485.

Davis, D.W., Lowenstein, T.K., Spencer, R.J., 1990. Melting behavior of fluid inclusions in laboratory-grown halite crystals in the systems $\mathrm{NaCl}-\mathrm{H}_{2} \mathrm{O}, \mathrm{NaCl}-\mathrm{KCl}-\mathrm{H}_{2} \mathrm{O}, \mathrm{NaCl}-\mathrm{MgCl}_{2}-\mathrm{H}_{2} \mathrm{O}$, and $\mathrm{NaCl}-\mathrm{CaCl}_{2}-\mathrm{H}_{2} \mathrm{O}$. Geochim. Cosmochim. Acta 54, 591-601.

Dubessy, J., Thiery, R., Canals, M., 1992. Modelling of phase equilibria involving mixed gas clathrates: application to the determination of molar volume of the vapour phase and salinity of the aqueous solution in fluid inclusions. Eur. J. Mineral. 45, 873884.

Ibarrola, E., Villaseca, C., Vialette, Y., Foster, J.M., Navidad, M., Peinado, M., Casquet, C., 1987. Dating of hercynian granites in the Sierra de Guadarrama Spanish Central System. In: Rueda (Ed.), Geología de los granitoides y rocas asociadas del Macizo Hespérico. Madrid, pp. 377-383.

Jacobs, G.K., Kerrick, D.M., 1981. Methane: an equation of state with application to the ternary system $\mathrm{H}_{2} \mathrm{O}-\mathrm{CO}_{2}-\mathrm{CH}_{4}$ Geochim. Cosmochim. Acta 45, 607-614.

Naden, J., 1996. CalcicBrine: a Microsoft Excel 5.0 Add-in for calculating salinities from microthermometric data in the system $\mathrm{NaCl}-\mathrm{CaCl}_{2}-\mathrm{H}_{2} \mathrm{O}$. Abstract. PACROFI VI, Wisconsin, USA, pp. 97-98.

Thiery, R., Vidal, J., Dubessy, J., 1994. Phase equilibria modelling applied to fluid inclusions liquid-vapour equilibria and calculation of the molar volume in the $\mathrm{CO}_{2}-\mathrm{CH}_{4}-\mathrm{N}_{2}$ system. Geochim. Cosmochim. Acta 58, 1073-1082.

Tomos, F., Casquet, C., Locutura, J., Collado, R., 1991. Fluid inclusion and geochimical evidence for fluid mixing in the genesis of $\mathrm{Ba}-\mathrm{F} \mathrm{Pb}-\mathrm{Zn}$ lodes of the Spanish Central System. Miner. Mag. $55,225-234$.

Tornos, F., Delgado, A., Casquet, C., Galindo, C., Reyes, E., 1996. La evolución isotópica de los fluidos ligados a los Sistemas Hidrotermales tardi y postvariscos del Sistema Central Español. Geogaceta 20, 1501-1503.

Villaseca, C., Barbero, L., Rogers, G., 1998. Crustal origin of Hercynian peraluminous granitic batholiths of Central Spain: petrological, geochemical and isotopic $\mathrm{Sr}$, Nd constraints. Lithos 43, 55-79

Vindel, E., López, J.A., Boiron, M.C., Cathelineau, M., Prieto, A.C., 1995. $P-V-T-X-f \mathrm{O}_{2}$ evolution from wolf ramite to sulphide depositional stages in intragranitic W-veins. An example from the Spanish Central System. Eur. J. Mineral. 7, 675-688.

Zhang, Y., Frantz, D., 1987. Determination of the homogenization temperatures and densities of supercritical fluids in the system $\mathrm{NaCl}-\mathrm{KCl}-\mathrm{CaCl}_{2}-\mathrm{H}_{2} \mathrm{O}$ using synthetic fluid inclusions. Chem. Geol. 64, 335-350. 